\title{
Decision Support System to determine students who are eligible to receive the scholarship of Indonesian Smart Carde(KIP) By Using Fuzzy Sugeno
}

\author{
Nanda Jarti \\ Computer Engineering, Universitas Ibnu Sina \\ nandaluthan@gmail.com
}

\begin{abstract}
Smart Indonesia Card (KIP) Is a state guarantee card for the continuity of college by providing freedom of tuition fees, fees given to underprivileged students so that they can continue their education. The problem that occurs in the provision of kip scholarships is that it is difficult to analyze students who are entitled to receive the scholarship so that standard criteria are needed such as proof of kip card, photocopy of report card, certificate of graduation, photo of student's house and photocopy of family card so that the scholarship given is right on target for students who entitled to receive such assistance. This study uses the Sugeno method by taking the Max value (the highest value) and using the or operator. The benefits of this research can be used as a decision-making system.
\end{abstract}

Keywords: Decision making system, Fuzzy Sugeno, KIP, Matlab

\section{Introduction}

Smart Indonesia Card (KIP) Is a state guarantee card for the continuity of college by providing freedom of tuition fees, fees given to underprivileged students so that they can continue their education. The problem that occurs in the provision of kip scholarships is that it is difficult to analyze students who are entitled to receive the scholarship so that standard criteria are needed such as proof of kip card, photocopy of report card, certificate of graduation, photo of student's house and photocopy of family card so that the scholarship given is right on target for students who entitled to receive such assistance. According to Research Tia Novianti (2019), Decision is an activity choose a strategy or action in solving problems. Aim this decision-making system is to get a target desired or an activity which must be implemented. System This decision is made by people together for carry out communication and results finally a way out. Term SPK can also be referred to as alternative. Decision support system Decision Support System (DSS) is a form of a system interactive information there various shapes available information, modeling, or data manipulation. Thus DSS this can be used as a handle in take a good decision in semi-structured conditions and conditions unstructured, where someone able to make decisions should have taken. Tech level DSS data is divided into 3 parts namely, 1.Decision support system Specific with helpful function shaped problem solving certain characteristics. 2.System decision support is a software that can build or develop a DSS. This system can build, design Specific. 3. Decision support system in the form of software and hardware for build a DSS that is Specific . In making a system decision making can using various methodson DSS, this method is expected able to complete the alternative match the criteria that have been set by an organization as well as companies. While Submissive the opinion of Agung Charisma and Yetman Erwandi (2019), System components Decision Support includes:1.Data Management System is all forms of activity related to the shape of the data relevant to the context decision to be chosen. 2. Model Management System is a system that displays various retrieval activity, setting and Model-shaped storage Quantitative capable of solving analysis for DSS. 3. Knowledge Base related to introduction problem and produce a final or temporary solution, This is a consideration in making 
a decision. 4. User Interface is a direct relationship between

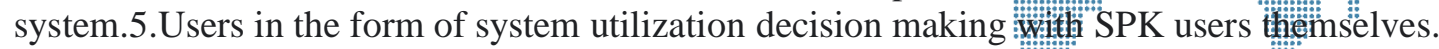

Fuzzy logic is a method that appropriate for mapping an in Starting point of modern concept of uncertainty is a paper created b.y Lofti A Zadeh (1965), where Zadeh introduced theory which has objects of fuzzy set that has a limit that imprecision and membership in fuzzy set, and not in the form logic true (true) or false (false), but expressed in degrees. Draft like this is called Fuzziness and The theory is called the Fuzzy Set Theory. Fuzziness can be defined as logic vague with regard to the semantics of a the event, phenomenon or statement alone. Often found in statements made by someone, evaluate and a decision Carolina (2016). Fuzzy logic part of a problem solving system methodology which can be implemented ina system. The part of solving fuzzy logic starts from small problems, medium and broad, so that it can be used as a problem solving system in taking a decision system [1],[2]. Fuzzy Logic can used in various branches of science such as in a disease diagnosis system (in medical science), in the field of marketing, economicsVi(research operation), water quality control, matching pattern (in engineering),Vprediction earthquakes and others [3].Broadly speaking, fuzzy logic can complete a mathematical calculation with the process ofcalculating and decide a value with true [4]. Can be used as a system decision support in determiningindicator of problem indicators[5].A intelligent computing capable of measuring range of values [6]. and predict a system [7]. Right now is logic fuzzy has been used by many people in a study, there are several reasons why people use logic fuzzy including: [8] 1. The concept that use easy to understand. 2. Fuzzy More Flexible. 3. Have a tolerance for data. 4. Based on the experience of experts without having to do activities training. 5. Using Formal Languageso that it is easy for people to understand lay.

\section{Research Methodology}

Research methodology is a reference in order to obtain maximum research results. This methodology describes information related to case resolution using the Sugeno method. The research steps to be carried out are:

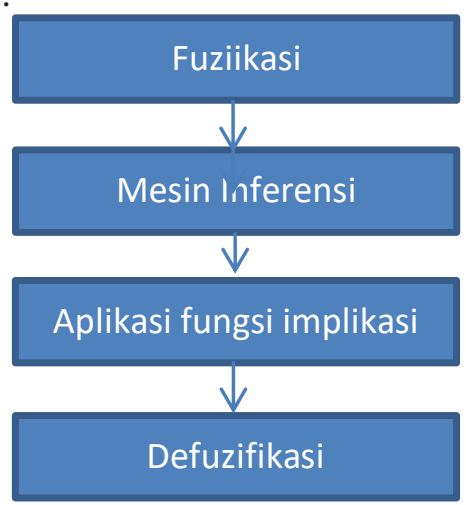

Figure 1. Research Design

\section{Results and Discussion}

Below is an analysis of data from a data set of data that has been processed including:

Table 1. Data Analysis

\begin{tabular}{|c|c|c|}
\hline Input & Proses & Decision \\
\hline 1. KIP Card & \multirow{5}{*}{ Metode Sugeno } & \multirow{5}{*}{$\begin{array}{l}\text { Worthy } \\
\text { Less Kite } \\
\text { Not feasible }\end{array}$} \\
\hline 2. Photocopy of Report Worth & & \\
\hline $\begin{array}{l}\text { 3. Certificate of Passing the Sugeno Less Lay } \\
\text { Method }\end{array}$ & & \\
\hline 4. Photo of student's house is not eligible & & \\
\hline 5. Copy of Family card & & \\
\hline
\end{tabular}


After grouping the input, Process and Output variable data, the neextente based on the fuzzy set domain, the data are grouped as follows:

Table 2. Domains of Fuzzy Sets...

\begin{tabular}{|c|c|c|c|}
\hline Variabel & Conversational Domain Set & Universe Fuzzy & Domain Set \\
\hline 1. KIP Card & $\begin{array}{ll}\text { a. } & \text { Exist } \\
\text { b. } & \text { In the process } \\
\text { c. } & \text { There is not any }\end{array}$ & $\begin{array}{l}{\left[\begin{array}{ll}80 & 100\end{array}\right]} \\
{\left[\begin{array}{ll}60 & 75\end{array}\right]} \\
{\left[\begin{array}{ll}40 & 55\end{array}\right]}\end{array}$ & $\begin{array}{l}{\left[\begin{array}{lll}80 & 85 & 100\end{array}\right]} \\
{\left[\begin{array}{lll}60 & 70 & 75\end{array}\right]} \\
{\left[\begin{array}{lll}40 & 50 & 55\end{array}\right]}\end{array}$ \\
\hline $\begin{array}{l}\text { 2. Photocopy of Report } \\
\text { Worth }\end{array}$ & $\begin{array}{l}\text { Exist } \\
\text { In the process } \\
\text { There is not any }\end{array}$ & 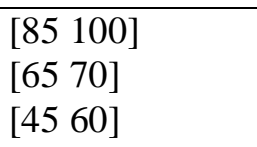 & $\begin{array}{l}{\left[\begin{array}{lll}85 & 90 & 100\end{array}\right]} \\
{\left[\begin{array}{lll}65 & 70 & 75\end{array}\right]} \\
{\left[\begin{array}{lll}45 & 55 & 60\end{array}\right]}\end{array}$ \\
\hline $\begin{array}{l}\text { 3. Certificate of Passing } \\
\text { the Sugeno Less Lay } \\
\text { Method }\end{array}$ & $\begin{array}{ll}\text { a. } & \text { Exist } \\
\text { b. } & \text { In the process } \\
\text { c. } & \text { There is not any }\end{array}$ & $\begin{array}{l}{\left[\begin{array}{ll}75 & 100\end{array}\right]} \\
{\left[\begin{array}{ll}55 & 70\end{array}\right]} \\
{\left[\begin{array}{ll}36 & 550]\end{array}\right.}\end{array}$ & $\begin{array}{l}{\left[\begin{array}{lll}75 & 85 & 100\end{array}\right]} \\
{\left[\begin{array}{lll}55 & 65 & 70\end{array}\right]} \\
{\left[\begin{array}{lll}36 & 46 & 55\end{array}\right]}\end{array}$ \\
\hline $\begin{array}{l}\text { 4hoto of student's } \\
\text { house is not eligible }\end{array}$ & $\begin{array}{ll}\text { a. } & \text { Exist } \\
\text { b. } & \text { In the process } \\
\text { c. } & \text { There is not any }\end{array}$ & $\begin{array}{l}{\left[\begin{array}{ll}88 & 100\end{array}\right]} \\
{\left[\begin{array}{ll}68 & 80\end{array}\right]} \\
{\left[\begin{array}{ll}48 & 65\end{array}\right]}\end{array}$ & 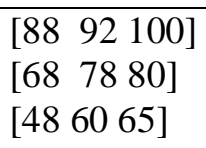 \\
\hline 5. Copy of Family card & \begin{tabular}{|ll} 
a. & Exist \\
b. & In the process \\
c. & There is not any
\end{tabular} & $\begin{array}{l}{\left[\begin{array}{ll}65 & 100\end{array}\right]} \\
{\left[\begin{array}{ll}30 & 60\end{array}\right]} \\
{\left[\begin{array}{ll}0 & 25\end{array}\right]}\end{array}$ & $\begin{array}{l}{\left[\begin{array}{lll}65 & 85 & 100\end{array}\right]} \\
{\left[\begin{array}{lll}30 & 50 & 60\end{array}\right]} \\
{\left[\begin{array}{lll}0 & 15 & 25\end{array}\right]}\end{array}$ \\
\hline 6. Decision & $\begin{array}{ll}\text { 1. } & \text { Worthy } \\
\text { 2. } & \text { Considered } \\
\text { 3. } & \text { Not feasible }\end{array}$ & $\begin{array}{l}{\left[\begin{array}{ll}80 & 100\end{array}\right]} \\
{\left[\begin{array}{ll}60 & 80\end{array}\right]} \\
{\left[\begin{array}{ll}40 & 60\end{array}\right]}\end{array}$ & $\begin{array}{l}{\left[\begin{array}{lll}80 & 90 & 100\end{array}\right]} \\
{\left[\begin{array}{lll}60 & 70 & 80\end{array}\right]} \\
{\left[\begin{array}{lll}40 & 50 & 60\end{array}\right]}\end{array}$ \\
\hline
\end{tabular}

The process of the Sugeno method uses the implication function by using the max or largest value in the fuzzy data testing process. Before proceeding to the next step, the rule search must be completed. The rules are obtained from the combination of fuzzy sets with matrix multiplication logic. The results of the Rule combination can be seen below:

Table 3. Formation of Rule

\begin{tabular}{|l|l|l|l|l|l|l|}
\hline No & $\begin{array}{c}\text { KIP } \\
\text { Card }\end{array}$ & $\begin{array}{c}\text { Photocopy of } \\
\text { Report Worth }\end{array}$ & $\begin{array}{c}\text { Certificate of } \\
\text { Passing the } \\
\text { Sugeno Less Lay } \\
\text { Method }\end{array}$ & $\begin{array}{c}\text { Photo of } \\
\text { student's house } \\
\text { is not eligible }\end{array}$ & $\begin{array}{c}\text { Copy } \\
\text { of } \\
\text { Family } \\
\text { card }\end{array}$ & Decision \\
\hline RI & Exist & Exist & Exist & Exist & Exist & Worthy \\
\hline R2 & Exist & In the process & Exist & Exist & Exist & Worthy \\
\hline R3 & Exist & Exist & In the process & In the process & Exist & Considered \\
\hline R4 & Exist & In the process & In the process & In the process & Exist & Considered \\
\hline R5 & Exist & Not feasible & Not feasible & Not feasible & Exist & $\begin{array}{l}\text { Not } \\
\text { feasible }\end{array}$ \\
\hline R6 & Exist & Not feasible & Not feasible & Not feasible & Exist & Considered \\
\hline
\end{tabular}

Table number 3 explains that the rule is obtained from a combination of fuzzy sets that have passed the data processing process. 
Test 1 formation of fuzzy sets

Kip Card input value $=85$, Copy of Report Card $=90$, Certificate ef el Graduation Home Photo $=92,=$ Photocopy of Family Card $=85$.

1) Kip cards are divided into 3 categories namely present, in progress, not present. If the value of $\mathrm{x}$ is known to be 85 then the solution is:

$$
\begin{array}{ll}
\mathrm{x} \text { None }[85] & =0 \\
\mathrm{x} \text { In Process [85] } & =0 \\
\mathrm{x} \text { Yes [85] } & =(\mathrm{x}-\mathrm{a}) /(\mathrm{b}-\mathrm{a}) \\
& =(85-80) /(85-80) \\
& =(5) /(5) \\
& =1
\end{array}
$$

2) Photocopy of Family card is divided into 3 categories, namely yes, in process, not available. If the value of $\mathrm{x}$ is 90 , then the solution is

$$
\begin{array}{rlrl}
\mathrm{x} \text { None }[90] & & 0 \\
\mathrm{x} \text { In Process [90] } & & 0 \\
\mathrm{x} \text { Yes [90] }(\mathrm{x}-\mathrm{a}) /(\mathrm{b}-\mathrm{a} & & =(90-85) /(90-85) \\
& & =(5) /(5) \\
& =1
\end{array}
$$

3) The graduation certificate is divided into 3 categories, namely yes, in process, and not available. If the value of $x$ is known to be 85 then the solution is

$$
\begin{array}{lll}
x \text { None }[85] & =0 \\
x \text { In Process [85] } & =0 \\
x \text { Yes [85] } & =(x-a) /(b-a) \\
& =(85-75) /(85-75) \\
& =(10) /(10) \\
& =1
\end{array}
$$

4) Student's house photos are divided into 3 categories, namely yes, in process, not available. If the value of $\mathrm{x}$ is 92 , then the solution is

$$
\begin{aligned}
& \mathrm{x} \text { None [92] } \quad=0 \\
& \mathrm{x} \text { In Process [92] } \quad=0 \\
& \mathrm{x} \text { Yes [92] } \quad=(\mathrm{x}-\mathrm{a}) /(\mathrm{b}-\mathrm{a}) \\
& =(92-88) /(92-88) \\
& =(4) /(4) \\
& =1
\end{aligned}
$$

5) Photocopy of Family card is divided into 3 categories, namely yes, in process, not available. If the value of $\mathrm{x}$ is known to be 85 then the solution is

$$
\begin{aligned}
& x \text { None }[85]=0 \\
& x \text { In Process [85] }=0 \\
& \mathrm{x} \text { Yes }[85]=(\mathrm{x}-\mathrm{a}) /(\mathrm{b}-\mathrm{a})=(85-65) / 85-65) \\
& =(20) /(20) \\
& =1
\end{aligned}
$$

The next step is to determine the Implication Function Application to get the final value of the logic fizzy Sugeno. The Implication Function Application uses the max value or the highest value. The value settlement process is as follows:

a) [RI] IF Existing kip card, or Photocopy of Ada's Family card, or Certificate of graduation Yes, or Photo of student's home, or Photocopy of Ada's family card THEN Eligible for KIP Scholarship.

b) [R2] IF Availability of kip card, or Photocopy of Family card in Process, or Certificate of graduation Yes, or Photo of Student's home, or Photocopy of Existing Family card THEN Eligible for KIP Scholarship. 


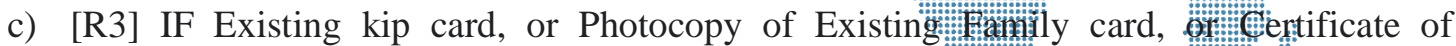
graduation In progress, or Photo of student's house in progecess, or Photoesopy of Existing Family card THEN Considered obtaining a KIP Scholarships:

d) [R4] IF Existing kip card, or Photocopy of Family card. in Process, or Certificate of Graduation in progress, or Photo of student's house in progress, or Photocopy of Existing Family card THEN Considered obtaining KIP Scholarship.

e) [R5] IF kip card available, or photocopy of family card is not available, or certificate of graduation is not available, or photo of student's house is not available, or photocopy of family card is there THEN Not eligible for KIP scholarship.

f) [R6] IF kip card is not available, or photocopy of family card is not available, or certificate of graduation is not available, or photo of student's home is not available, or photocopy of family card is there THEN Not eligible for KIP scholarship.

The final search for the value of defuzzification in determining the decision-making system of students who are entitled to receive KIS scholarships is:

$$
\begin{aligned}
& =(85 * 1)(90 * 1)(85 * 1)(92 * 1)(85 * 1) \\
& =85+90+85+92+85 \\
& =437 / 5 \\
& =87,4
\end{aligned}
$$

From the results of the defuzzification obtained a value of 87.4 which is in the range with the decision that students are entitled to receive KIS scholarships. To get another value, just enter the $\mathrm{x}$ value of each variable so that it gets the final value.

\section{Conclusion}

Based on the research results obtained, the researchers can conclude several parts including:

a) To take a decision support system in determining students who are entitled to receive scholarships, it is necessary to pay attention to input variables including Kip Card, Photo Copy of Report Card, Graduation Certificate, Student's Home Photo and Photo Copy of Family Card.

b) This fuzzy Sugeno method can help determine students who are eligible to receive the Kip card scholarship.

c) Fuzzy logic can be used as a decision-making system in determining which students are entitled to receive the Kip card scholarship.

\section{References}

[1] Agung K.H., \& Erwadi Yetman. (2019). Decision Support System Election of the Chairman of the Executive Board Student With Simple Method

Additive Weighting. JSAI 2(1), 1-5.

[2] Charolina, Y. (2016). Decision Support System To Determine The Annual Bonus Using The Mamdani Type Fuzzy Logic Method. Information Technology, 12(2), 42-53.

[3] Rizki, S.N. (2018). Fuzzy logic predict accident rate work at PT. Galang Kapal in the city of Batam. Digital Zone: Journal Information and Communication Technology, 9(2), 151-161. https://doi.org/10.31849/digitalzon e.v9i2.180.

[4] Setiani Asih, M. (2018). System Fuzzy Decision Support Mamdani on the Watering Tool Auto Crop. System Journal Information, 5341(April), 1.

[5] Irawan, M. D., \& Herviana, H. (2019). Logic Implementation Fuzzy in Determining Majors for New School Students Vocational High School (Smk)

Country 1 White Water. Journal Information Technology, 2(2), 129. https://doi.org/10.36294/jurti.v2i2. 


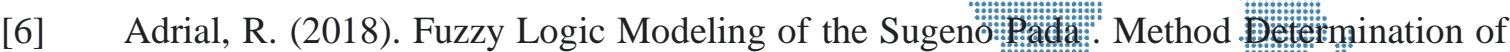
Diabetes Mellitus Type Using MATLAB. Journal Scexentific Informa https://doi.org/10.33884/jif.v6i01.

[7] Rizki, S. N., \& Tipa2, H. (2019). Fuzzy Inference Implementation System To Optimize Connection Load Sharing. Digital Zone: Journal of Information and Communication Technology, $\mathrm{x}(1), 1-7$.

[8] Larasati, I., Setiawan, B.D., \& Data, M. (2018). Election Fuzzy Inference System Rules Mamdani Using Particle Swarm Optimization Algorithm in Watering System Sistem Automatic On Tomato Plants. Journal of Technology Development Jurnal Information and Computer Science (JPTIIK) Universitas Brawijaya, 2(11), 5525-5534.

[9] Pambudi, R. A., Setiawan, B. D., \& Wijoyo, S. H. (2018). Implementation of Fuzzy Time Series for Predicting the Number of Occurrence of Hotspots. Journal of Information Technology Development Dan Computer Science (J-PTIIK) Universitas Brawijaya, 2(11), 4767-4776.

[10] Wahyudi, I., Bahri, S., \& Handayani, P. (2019). Cultural Recognition Learning App Indonesia. V(1), 135-138.https://doi.org/10.31294/jtk.v4i2.

\section{Authors}

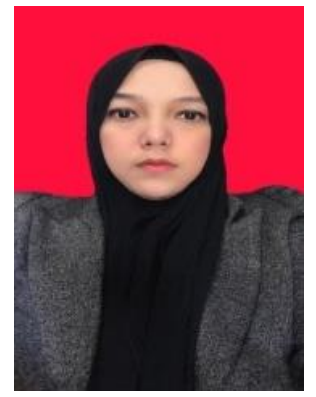

My name is Nanda Jarti, I teach at IBNU SINA University, I have an undergraduate and postgraduate education level at Putra Indonesia University`YPTK' 